\title{
Study on Odor Detection and Microbial Identification Method in Closed Water Area of Jiangxi Province
}

\author{
Ziyan Yang ${ }^{1,2,3}$, Minkai Dong ${ }^{4 *}$, Yifei Guo ${ }^{3,5}$, Junfeng $\mathrm{Wu}^{3}$ \\ ${ }^{1}$ School of Environment and Municipal Engineering, North China University of Water Resources and Electric Power, \\ Zhengzhou 450000, China \\ ${ }^{2}$ Henan Key Laboratory of Water Environment Simulation and Treatment, Zhengzhou 450000, China \\ ${ }^{3}$ Henan University of Urban Construction, Henan Province Key Laboratory of Water Pollution Control and Rehabilitation \\ Technology, Pingdingshan 467036, China \\ ${ }^{4}$ School of Public Economics \& Administration, Shanghai University of Finance and Economics, Shanghai 200433, China \\ ${ }^{5}$ Zhengzhou University, College of Chemistry and Molecular Engineering, Zhengzhou 450001, China
}

Corresponding Author Email: dong.minkai@mail.shufe.edu.cn

https://doi.org/10.18280/i2m.180113

Received: 11 December 2018

Accepted: 3 February 2019

\section{Keywords:}

closed water area, odor detection, microbial decomposition

\begin{abstract}
The problem of odor in water has become one of the most concerned issues of the public. The odor emitted from water will not only lead to deterioration of water quality, but also increase the cost of water treatment, which will have an adverse impact on the ecological environment. This paper takes the Doushui Lake water area as an example to study the odor detection and microbial identification methods by combining Sensory-GC with GC/MS, the research results show that: the water body of the Doushui Lake has a variety of odors, mainly grassy smell, musty smell, earthy smell, pungent smell, liquorice smell and burnt smell. There are four main substances, TCA, Geosmin, $\beta$-Cyclocitral and $\alpha$-Cedrol, and their highest concentrations reach $124 \mathrm{ng} / \mathrm{L}, 97 \mathrm{ng} / \mathrm{L}, 43 \mathrm{ng} / \mathrm{L}$ and $48 \mathrm{ng} / \mathrm{L}$, respectively. The decomposition of algae by microorganisms produces volatile gas compounds, mainly are dimethyl disulfide and dimethyl tetra sulfide. In the decomposition process, the contents of these two compounds both increase first and decrease later.
\end{abstract}

\section{INTRODUCTION}

With the continuous improvement of people's living standards, the requirements for drinking water quality become more demanding. However, due to the acceleration of industrialization, water pollution has become increasingly serious [1]. The problem of odor in water has become one of the most concerned issues of the public. The odor emitted from the water will not only lead to deterioration of water quality, but also increase the cost of water treatment, which will have an adverse impact on the ecological environment [2]. However, some microorganisms contained in the water can oxidize and decompose odorous substances, and can effectively remove odor substances. Therefore, it is urgent to find out the sources and causes of odorous substances in water bodies and find a quick and effective odor removal method [3].

At present, the problem of water odor has aroused widespread concern around the world. Many experts and scholars at home and abroad have conducted targeted research and achieved numerous research results. Some scholars have studied the types and sources of odorous substances in water bodies $[4,5]$; some scholars have studied the detection methods of odor substances in water [6-8]; and some scholars have studied the treatment of odorous substances in water [9, 10]. Taking the water area of the Doushui Lake in Jiangxi Province as an example, this paper studies the odor detection and microbial identification methods, which has intensified practical significance and can provide useful reference for the study of odor in other water bodies.

\section{ANALYSIS OF RELATED THEORIES}

\subsection{Odor detection of water areas}

At present, the odors in water bodies mainly include: earthy smell, rancid smell, fishy smell and grassy smell caused by plankton; smell of chlorobenzene and tar caused by industrial sewage [11]. The odor substances are mainly: 2-isopropyl-2methoxypyrazine (IPMP), Geosmin, 2, 3, 6-trichloroanisole (TCA), etc. The causes of odor in water are mainly divided into two categories: one is caused by natural factors such as natural substances (such as sulfate, iron) in the soil layer, or hydrogen sulfide produced by lake sediment, or produced by the reproduction and rot of animals, plants and microorganisms (such as algae, zooplankton, various bacteria, etc.) in the water. The other category is caused by human factors, mainly the discharge of a large amount of industrial wastewater and domestic sewage into water bodies, and the wastewater can produce odorous substances [12].

For the control of odorous substances, the more traditional treatment processes mainly include coagulation, sedimentation, sand filtration, etc. Although these methods have a certain effect on the removal of odor, the effect is not ideal, and it is also necessary to rely on other advanced treatment processes, such as adding odor control agents (activated carbon, potassium permanganate, liquid chlorine, etc.) for the treatment [13].

The reaction formula of using potassium permanganate to remove hydrogen sulfide from water is: 
Usually, the $\mathrm{pH}$ value in the water body needs to be controlled at 6.5-7, and the generated sulfur and manganese dioxide that other precipitate can be removed by filtration. If the $\mathrm{pH}$ value is too high, the following reaction will occur:

$\mathrm{MnO}_{4}{ }^{-}+3 \mathrm{Fe}^{2+}+4 \mathrm{H}^{+} \rightarrow 3 \mathrm{Fe}^{3+}+\mathrm{MnO}_{2}+2 \mathrm{H}_{2} \mathrm{O}$

$2 \mathrm{MnO}_{4}{ }^{-}+3 \mathrm{Mn}^{2+}+2 \mathrm{H}_{2} \mathrm{O} \rightarrow 5 \mathrm{MnO}_{2}+4 \mathrm{H}^{+}$

The higher the $\mathrm{pH}$ of the water, the faster the reaction formulas (2) and (3) proceed.

If potassium permanganate reacts with reducing substances in the water, manganese dioxide is produced. Manganese dioxide has a strong adsorption capacity, and odorous substances in water can be adsorbed to the surface of manganese dioxide and precipitated and removed [14]. The chemical reaction formula is:

$\mathrm{MMn}^{2+}+\mathrm{O}_{2} \rightarrow \mathrm{MnO}_{2(\mathrm{~s})}$

$\mathrm{MMn}^{2+}+\mathrm{MnO}_{2(\mathrm{~s})}+\mathrm{O}_{2} \rightarrow 2 \mathrm{MnO}_{2(\mathrm{~s})}$

When the $\mathrm{pH}$ value of the water is 7.5-8, the removal rate of the odorous substance is higher.

\subsection{Microorganisms in water area}

Besides natural dwellers, microorganisms in water also include some foreign pathogenic microorganisms. Microorganisms that enter the water body from the outside are gradually dying due to their unsuitability for environmental conditions, but a small portion can survive for a long time. Most of the bacteria isolated from the water environment are Gram-negative bacilli. Bacteria with sheaths and appendages are mostly aquatic. As a primary producer, photosynthetic bacteria are particularly important in the circulation of water body elements [15].

In closed water area, the $\mathrm{pH}$ range is between 6.5 and 8.5 , which is suitable for the growth of most microorganisms. Since oxygen is less soluble in water and is easily depleted by microorganisms, oxygen is an important limiting factor for the growth of microorganisms [16].

\section{ODOR DETECTION AND IDENTIFICATION OF MICROORGANISMS}

\subsection{Odor detection}

There are many lakes in Jiangxi Province, among which there are three large closed water areas, namely the water areas of Xiannv Lake, Zhelin Lake and Doushui Lake. This paper selects the Doushui Lake as the research object and uses Sensory-GC to study the odor components in water body, it also uses GC/MS combination to monitor the odorous compounds in the water body.

First, set up 4 water sample collection points in Doushui Lake water area, and wash the glassware with acetone and dichloromethane before collecting the water samples. After sampling, label the glassware and record it and send back to the lab for testing.

Through the detection of the collected water samples, the

main odors and main substances contained in Doushui Lake water area from March to May 2017 are shown in Table 1.

Table 1. Main odors and substances contained in Doushui Lake water area from March to May 2017

\begin{tabular}{|c|c|c|c|}
\hline $\begin{array}{c}\text { Odor } \\
\text { description }\end{array}$ & $\begin{array}{c}\text { Odor } \\
\text { intensity }\end{array}$ & $\begin{array}{c}\text { Check water } \\
\text { sample/month }\end{array}$ & Note \\
\hline Grassy & B & $\begin{array}{c}\text { March, April, } \\
\text { May }\end{array}$ & $\begin{array}{c}2,3,6- \\
\text { trichloroanisole, } \\
\text { TCA }\end{array}$ \\
\hline Geosmin & B & $\begin{array}{c}\text { March, April, } \\
\text { May }\end{array}$ & Geosmin \\
\hline Earthy & $\mathrm{C}$ & March & \\
\hline $\begin{array}{l}\text { Pungent } \\
\text { smell }\end{array}$ & A & $\begin{array}{c}\text { March, April, } \\
\text { May }\end{array}$ & \\
\hline Liquorice & $\mathrm{C}$ & May & $\beta$-Cyclocitral \\
\hline Burnt smell & A & $\begin{array}{c}\text { March, April, } \\
\text { May }\end{array}$ & $\alpha$-Cedrol \\
\hline
\end{tabular}

Figure 1 is a comparison of the concentrations of TCA at different sampling times for each water sample collection point. From the data in the figure, it can be found that the average concentration of TCA is the highest in May, and the concentrations in March and April are not much different. The concentrations of water sample collection points No. 1 and No. 2 were the lowest in April and the highest in May; the concentrations of water sample collection points No. 3 and No. 4 showed a gradual increase.

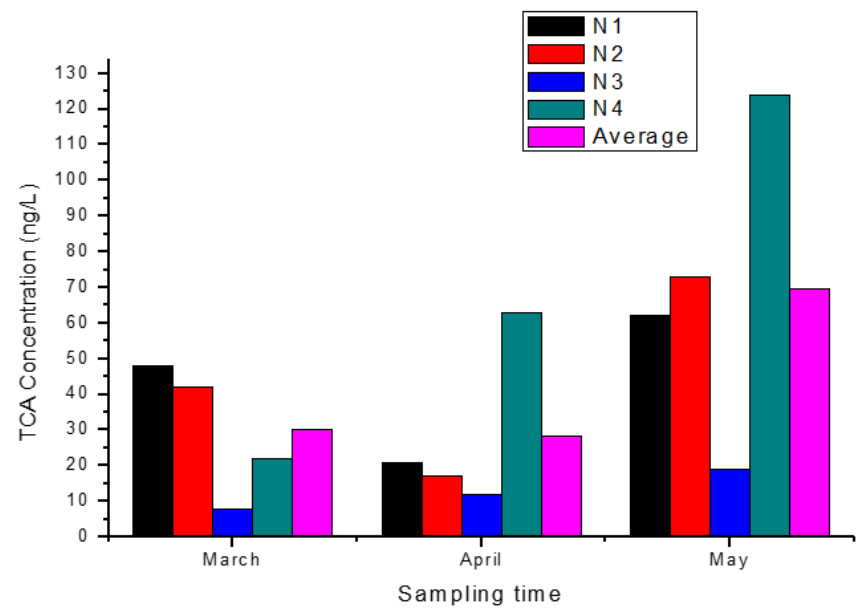

Figure 1. TCA concentration profile

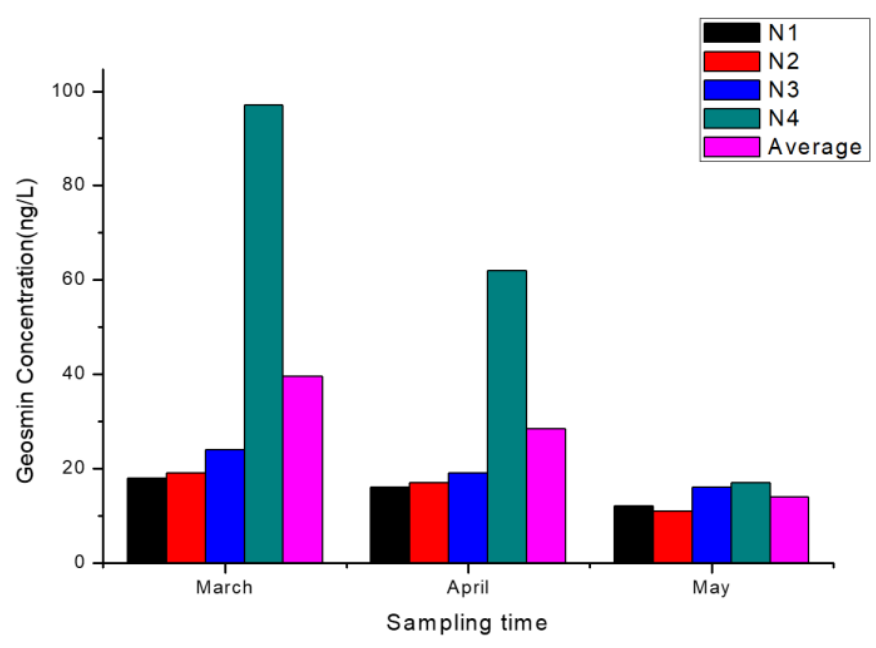

Figure 2. Geosmin concentration profile 
Figure 2 is a comparison of the concentrations of Geosmin at different sampling times for each water sample collection point. From the data in the figure, it can be found that the average concentration of Geosmin is the highest in March, and the concentrations of the four water sample collection points tend to decrease gradually, among them, the concentration of the water sample collection point No. 4 is significantly higher than that of other water sample collection points.

Figure 3 is a comparison of $\beta$-Cyclocitral concentrations of each water sample collection point at May 2017. From the data in the figure, it can be found that the concentration of $\beta$ Cyclocitral is the highest at collection point No. 2, which is 43 $\mathrm{ng} / \mathrm{L}$; the lowest concentration is at the No. 3 collection point, it is $18 \mathrm{ng} / \mathrm{L}$. The average concentration is $28.5 \mathrm{ng} / \mathrm{L}$.

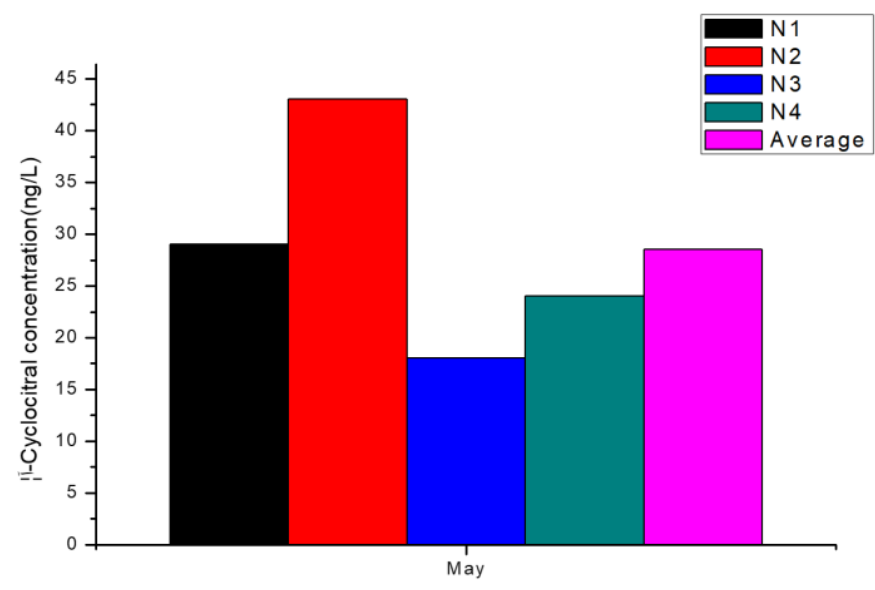

Figure 3. $\beta$-Cyclocitral concentration profile

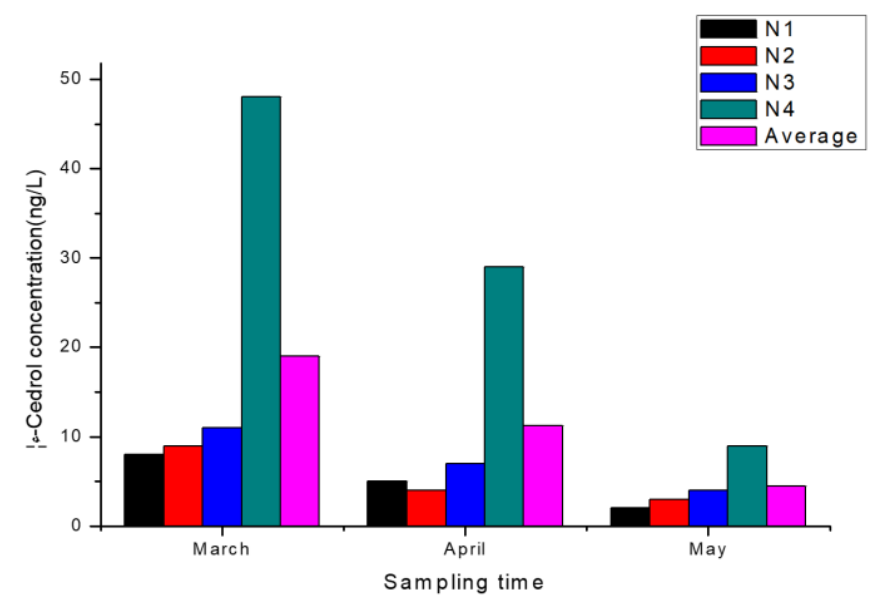

Figure 4. $\alpha$-Cedrol concentration profile

Figure 4 is a comparison of $\alpha$-Cedrol concentrations of each water sample collection point at different sampling times. From the data in the figure, it can be found that the average concentration of $\alpha$-Cedrol is the highest in March, and the concentrations of the four water sample collection points tend to decrease gradually. Among them, the concentration of the water sample collection point No. 4 is significantly higher than the concentration of other water sample collection points.

\subsection{Microbial decomposition}

Closed water areas are prone to produce large amounts of algae, and the decomposition of algae by microorganisms produces volatile gas compounds, which are mainly dimethyl disulfide and dimethyl amine. The decomposition of microorganisms is affected by temperature, and this paper mainly sets three temperature conditions of $15{ }^{\circ} \mathrm{C}, 25^{\circ} \mathrm{C}$ and $35{ }^{\circ} \mathrm{C}$ to study the composition of algae decomposition products and the changes in their contents.

First, take some algae from the Doushui Lake water area, filter the water through a gauze and place it into a glassware, then culture it in the dark, and record the sample data at different temperatures.

Table 2. Regression equation and correlation coefficient of each substance under different room temperature

\begin{tabular}{|c|c|c|c|}
\hline Temperature & $\begin{array}{c}\text { Compound } \\
\text { name }\end{array}$ & $\begin{array}{c}\text { Regression } \\
\text { equation }\end{array}$ & $\begin{array}{l}\text { Correlation } \\
\text { coefficient }\end{array}$ \\
\hline \multirow{2}{*}{$15^{\circ} \mathrm{C}$} & $\begin{array}{l}\text { Dimethyl } \\
\text { disulfide }\end{array}$ & $\begin{array}{c}\mathrm{Y}=- \\
0.08624+2.438 \mathrm{X}\end{array}$ & 0.9983 \\
\hline & $\begin{array}{l}\text { Dimethyl } \\
\text { amine }\end{array}$ & $\begin{array}{c}\mathrm{Y}=- \\
0.00643+1.349 \mathrm{X}\end{array}$ & 0.9994 \\
\hline \multirow{2}{*}{$25^{\circ} \mathrm{C}$} & $\begin{array}{l}\text { Dimethyl } \\
\text { disulfide }\end{array}$ & $\begin{array}{c}\mathrm{Y}=- \\
0.14872+6.539 \mathrm{X}\end{array}$ & 0.9986 \\
\hline & $\begin{array}{l}\text { Dimethyl } \\
\text { amine }\end{array}$ & $\begin{array}{c}Y=- \\
0.00853+1.572 \mathrm{X}\end{array}$ & 0.9979 \\
\hline \multirow{2}{*}{$35^{\circ} \mathrm{C}$} & $\begin{array}{l}\text { Dimethyl } \\
\text { disulfide }\end{array}$ & $\begin{array}{c}Y=- \\
0.17592+7.423 \mathrm{X}\end{array}$ & 0.9981 \\
\hline & $\begin{array}{l}\text { Dimethyl } \\
\text { amine }\end{array}$ & $\begin{array}{c}\mathrm{Y}=- \\
0.04573+2.659 \mathrm{X}\end{array}$ & 0.9995 \\
\hline
\end{tabular}

From the data in Table 2, it can be found that there is a linear relationship between dimethyl disulfide and dimethyl amine at different temperatures, and the correlation coefficient exceeds 0.9975 .

In addition, in the process of detecting algae in the Doushui Lake water area, it was found that the contents of dimethyl disulfide and dimethyl amine both increased first and then decreased under different temperature conditions.

\section{CONCLUSION}

(1) This paper used Sensory-GC and GC/MS combination to study the odor in the water body of Doushui Lake water area in Jiangxi Province. It was found that the water body of Doushui Lake has many odors, mainly are grassy smell, musty smell, earthy smell, pungent smell, liquorice smell and burnt smell, and there are four main substances, TCA, Geosmin, $\beta$ Cyclocitral and $\alpha$-Cedrol, and their highest concentrations reach $124 \mathrm{ng} / \mathrm{L}, 97 \mathrm{ng} / \mathrm{L}, 43 \mathrm{ng} / \mathrm{L}$ and $48 \mathrm{ng} / \mathrm{L}$, respectively.

(2) The decomposition of algae by microorganisms produces volatile gas compounds, mainly are dimethyl disulfide and dimethyl amine, and the content of these two compounds both increased first and then decreased during the decomposition process.

\section{ACKNOWLEDGEMENTS}

Henan Science and Technology Project "Study on Biological Toxicity of Water Quality in Henan Province" (No.152102310343). Supported by the Opening Project of Henan Province Key Laboratory of Water Pollution Control and Rehabilitation Technology. 


\section{REFERENCES}

[1] Furton KG, Hong Y, Hsu YL, Luo T, Rose S, Walton J. (2002). Identification of odor signature chemicals in cocaine using solid-phase microextraction-gas chromatography and detector-dog response to isolated compounds spiked on U.S. paper currency. Journal of Chromatographic Science 40(3): 147-155. https://doi.org/10.1093/chromsci/40.3.147

[2] James AL, Perry JD, Rigby A, Stanforth SP. (2007). Synthesis and evaluation of novel chromogenic aminopeptidase substrates for microorganism detection and identification. Bioorganic \& Medicinal Chemistry Letters 17(5): 1418-1421. https://doi.org/10.1016/j.bmcl.2006.11.088

[3] Cecchini F, Iacumin L, Fontanot M, Comi G, Manzano M. (2012). Identification of the unculturable bacteria candidatus arthromitus in the intestinal content of trouts using dot blot and southern blot techniques. Veterinary Microbiology 156(3-4): 389-394 https://doi.org/10.1016/j.vetmic.2011.11.020

[4] Demirev AP, Feldman A, Kowalski P, Lin JS. (2005). Top-down proteomics for rapid identification of intact microorganisms. Analytical Chemistry 77(22): 74557461. https://doi.org/10.1021/ac051419g

[5] Doty RL, Perl DP, Steele JC, Chen KM, Pierce JD, Reyes P. (1991). Odor identification deficit of the parkinsonism-dementia complex of Guam. Neurology 41(5 Suppl 2 2): https://doi.org/10.1212/wnl.41.5_suppl_2.77

[6] Buck GE. (1989). Nonculture methods for detection and identification of microorganisms in clinical specimens. Pediatric Clinics of North America 36(1): 95-112. https://doi.org/10.1016/s0031-3955(16)36618-4

[7] Wang Z, Ma Y, Zhao G, Liao X, Chen F, Wu J. (2006). Influence of gamma irradiation on enzyme, microorganism, and flavor of cantaloupe (cucumis melo, 1.) juice. Journal of Food Science 71(6): M215-M220. https://doi.org/10.1111/j.1750-3841.2006.00097.x

[8] Mgode GF, Weetjens BJ, Nawrath T, Cox C, Jubitana M, Machang'U RS. (2012). Diagnosis of tuberculosis by trained african giant pouched rats and confounding impact of pathogens and microflora of the respiratory tract. Journal of Clinical Microbiology 50(2): 274-280. https://doi.org/10.1128/jcm.01199-11
[9] Chen YC, Higgins MJ, Beightol SM, Murthy SN, Toffey WE. (2011). Anaerobically digested biosolids odor generation and pathogen indicator regrowth after dewatering. Water Research 45(8): 2616-2626. https://doi.org/10.1016/j.watres.2011.02.014

[10] Claeson AS, Sunesson AL. (2005). Identification using versatile sampling and analytical methods of volatile compounds from streptomyces albidoflavus grown on four humid building materials and one synthetic medium. Indoor Air 15(s9): 41-47. https://doi.org/10.1111/j.16000668.2005.00343.x

[11] Stivarius MR, Pohlman FW, Mcelyea KS, Apple JK. (2002). Microbial, instrumental color and sensory color and odor characteristics of ground beef produced from beef trimmings treated with ozone or chlorine dioxide. Meat 6cience 60(3): 299-305. https://doi.org/10.1016/s0309-1740(01)00139-5

[12] Spiehs MJ, Brown-Brandl TM, Parker DB, Miller DN, Jaderborg JP, DiCostanzo A, Berry ED, Wells JE. (2014). Use of wood-based materials in beef bedded manure packs: 2. effect on odorous volatile organic compounds, odor activity value, and nutrient concentrations. Journal of Environmental Quality 43(4): 1195-1206. https://doi.org/10.2134/jeq2013.05.0165

[13] Doty RL, Reyes PF, Gregor TP. (1987). Presence of both odor identification and detection deficits in alzheimer's disease. Brain Research Bulletin 18(5): 597-600. https://doi.org/10.1016/0361-9230(87)90129-8

[14] Bodyak N, Slotnick B. (1999). Performance of mice in an automated olfactometer: Odor detection, discrimination andodor memory. Chemical Senses 24(6): 637-645. https://doi.org/10.1093/chemse/24.6.637

[15] Doty RL, Risser JM. (1990). Influence of the d-2 dopamine receptor agonist quinpirole on the odor detection performance of rats before and after spiperone administration. Psychopharmacology 100(2): 285-285. https://doi.org/10.1007/bf02244421

[16] Pietras RJ, Moulton DG. (1974). Hormonal influences on odor detection in rats: changes associated with the estrous cycle, pseudopregnancy, ovariectomy, and administration of testosterone propionate. Physiology \& Behavior 12(3): 475-491. https://doi.org/10.1016/00319384(74)90125-5 